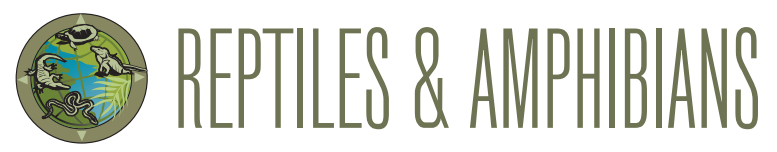

\title{
Westernmost Record of the Brahminy Blindsnake, Virgotyphlops braminus (Squamata: Typhlopidae), in Cuba
}

\author{
Luis F. de Armas $^{1}$ and Manuel Iturriaga ${ }^{2}$
}

${ }^{1}$ P.O. Box 4327, San Antonio de los Baños, Artemisa 38100, Cuba (luisdearmas1945@gmail.com [corresponding author]) ${ }^{2}$ Instituto de Ecología y Sistemática, Carretera de Varona No. 11835, entre Oriente y Lindero, Reparto Parajón, Municipio Boyeros, La Habana 19, C.P. 11900, Cuba (manueliturriaga@gmail.com)

$\mathrm{T}$ en non-native species of amphibians and reptiles are established in Cuba (Borroto-Páez et al. 2015), and a potentially invasive anuran species was recently recorded in western Cuba (Rodríguez-Cabrera et al. 2018). Of these species, the only ophidian is the Brahminy Blindsnake, Virgotyphlops braminus (Typhlopidae).

Brahminy Blindsnakes are small (adult SVL $=100-150$ $\mathrm{mm}$ ) obligatory parthenogenetic scolecophidians that are native to southern Asia but which have been widely introduced in tropical and subtropical regions throughout the world (Wallach 2020). Both Greater and Lesser Antillean populations have been documented (Powell et al. 2011; Borroto-Páez et al. 2015). In Cuba, this species occurs in sev-

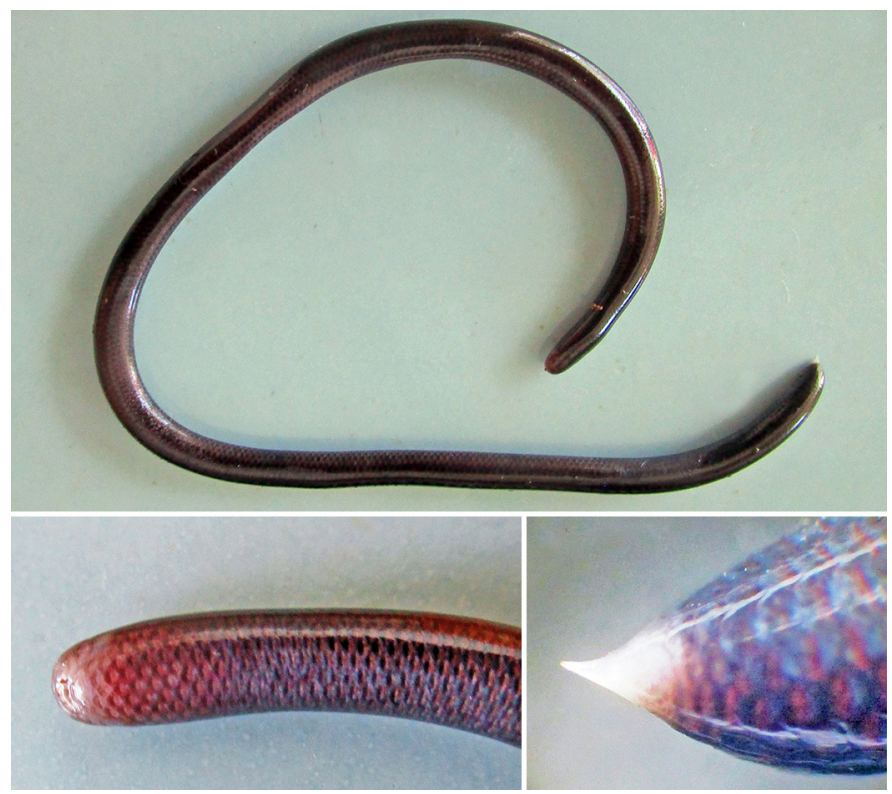

Fig. 1. An adult Brahminy Blindsnake (Virgotyphlops braminus) from San Antonio de los Baños, Artemisa Province, Cuba: Habitus (top), ventral aspect of the anterior region (lower left), and the tip of the tail (lower right). Photographs by Luis F. de Armas.

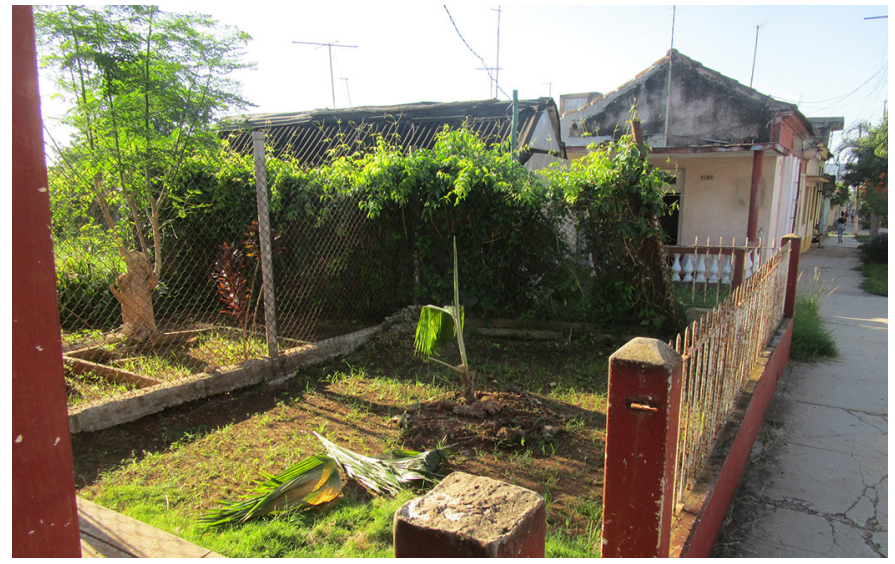

Fig. 2. Precise location in San Antonio de los Baños, Artemisa Province, Cuba, where two adult Brahminy Blindsnakes (Virgotyphlops braminus) were collected. Photograph by Luis F. de Armas.

eral localities in La Habana (Díaz and Cádiz 2014; BorrotoPáez et al. 2015), Guantanamo, and Villa Clara Provinces (Wallach, in press).

On 14 September 2021, the senior author collected two adult Brahminy Blindsnakes (SVLs $=132 \mathrm{~mm}$ and 126 $\mathrm{mm}$ ) (Fig. 1) in the garden of an urban home at 70th Street \#2503, San Antonio de los Baños, Artemisa Province, Cuba (22 $53^{\prime} 36.49^{\prime \prime} \mathrm{N}, 82^{\circ} 30^{\prime} 35.21^{\prime \prime W}$; elev. $74 \mathrm{~m}$ asl), while planting a palm tree (Fig. 2). This is the first record of this species in Artemisa Province and also the westernmost Cuban locality for the species (Fig. 3).

Specimens have been deposited in the herpetological collection of the Institute of Ecology and Systematics, La Habana, Cuba (CZACC 4.13497-8). The identity of the species was confirmed from photographs by Van Wallach.

Díaz and Cádiz (2014) suggested that these blindsnakes arrived accidentally in Cuba with imported shipments of ornamental plants, and the founders of the newly discovered population almost certainly were transported from La 


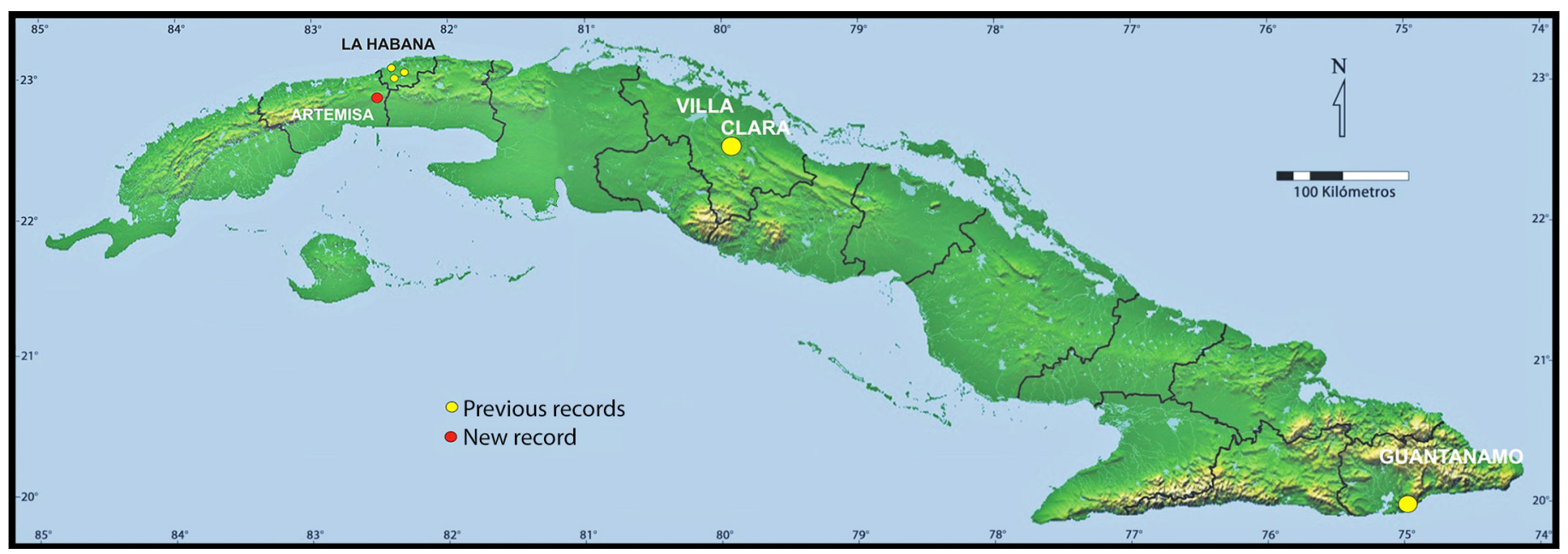

Fig. 3. Distribution of the Brahminy Blindsnake (Virgotyphlops braminus) in Cuba, including data in Wallach (in press).

Habana to San Antonio de los Baños, most likely in containers of plants.

\section{Acknowledgement}

Van Wallach (Cambridge, Massachusetts, USA) graciously provided a copy of his manuscript currently in press and granted permission to cite some new Cuban records for Virgotyphlops braminus contained therein.

\section{Literature Cited}

Borroto-Páez, R., R. Alonso Bosch, B.A. Fabres, and O. Álvarez García 2015. Introduced amphibians and reptiles in the Cuban Archipelago. Herpetological Conservation and Biology 10: 985-1012.

Díaz, L.M. and A. Cádiz. 2014. First record of the Brahminy Blindsnake, Indotyphlops braminus (Squamata: Typhlopidae), in Cuba. Reptiles \& Amphibians 21: 140-
141. https://doi.org/10.17161/randa.v21i4.14016.

Powell, R., R.W. Henderson, M.C. Farmer, M. Breuil, A.C. Echternacht, G. van Buurt, C.M. Romagosa, and G. Perry. 2011. Introduced amphibians and reptiles in the Greater Caribbean: Patterns and conservation implications, pp. 63-143. In: A. Hailey, B.S. Wilson, and J.A. Horrocks (eds.), Conservation of Caribbean Island Herpetofaunas. Volume 1: Conservation Biology and the Wider Caribbean. Brill, Leiden, The Netherlands.

Rodríguez-Cabrera, T.M., L.Y. García-Padrón, A.R. Acosta Galvis, R.O. de Sá, and R. Alonso Bosch. 2018. First record of the genus Leptodactylus (Anura: Leptodactylidae) in Cuba: Leptodactylus fragilis, a biological invasion? Journal of Natural History 52: 1883-1892. https://doi.org/10.1080/00222933.201 8.1498549 .

Wallach, V. 2020. How to easily identify the flowerpot blindsnake, Indotyphlops braminus (Daudin, 1803), with proposal of a new genus (Serpentes: Typhlopidae).POD@RCIS n.s. 11: 4-12.

Wallach, V. In press. The geographic distribution, habitat elevation, and chronological dispersal of Virgotyphlops braminus (Daudin, 1803) around the world (Squamata: Typhlopidae). Zootaxa. 